\title{
Group Rights, Group Intentions, and the Value of Groups
}

David Luban

Georgetown University Law Center, luband@law.georgetown.edu

This paper can be downloaded free of charge from:

https://scholarship.law.georgetown.edu/facpub/2039

https://ssrn.com/abstract=3135320

David Luban, Group Rights, Group Intentions, and the Value of Groups, J. Genocide Res.

(forthcoming)

This open-access article is brought to you by the Georgetown Law Library. Posted with permission of the author.

Follow this and additional works at: https://scholarship.law.georgetown.edu/facpub 


\title{
Group Rights, Group Intentions, and the Value of Groups
}

\author{
David Luban \\ Georgetown University Law Center
}

[forthcoming, Journal of Genocide Research]

\begin{abstract}
This paper is part of a symposium on Berel Lang's 2016 book Genocide: The Act as Idea (University of Pennsylvania Press). While agreeing with much of Lang's important argument about the moral significance of criminalizing genocide as a crime against groups, I raise several objections and questions. Lang ties the crime of genocide to group rights, specifically the right of groups to exist in the future; I argue that the concept of group rights obscures rather than clarifies the crime of genocide. What matters is not the rights of groups but the value of groups, both to their members and to non-members. The two leading accounts are those of Arendt and Lemkin, one pluralist and one universalist, and Lang leaves the issue dividing them unresolved. He also neglects an important objection to the criminalization of genocide, namely that placing so much emphasis on groups invites just the kind of tribalist mentality that fosters genocide. Finally, I raise doubts about Lang's claim that anyone who commits genocide knows it is wrong.
\end{abstract}

Berel Lang has written a deeply thought and thought-provoking book on the distinctive moral importance of the concept of genocide. Lang's central claim is that "genocide" is an indispensable moral and legal concept, because it names a unique kind of crime: the murder of a group, over and above the murder of individuals in the group. Perceptively, Lang argues that genocide is also a radical assault on individual autonomy, because victims are destroyed for reasons having nothing to do with their own acts or choices (34-36). This double nature of the crime - an assault on groups and an assault on individuals - gives genocide a unique status. This is one of the book's most valuable insights. The crimes of persecution and apartheid, as defined in various international treaties, have the same double character, but genocide alone aims not simply at group oppression but group murder.

In the comments that follow, I will examine several aspects of the focus on groups and morality that is so central to Lang's analyses of the ideas behind acts of genocide. 


\section{Group rights}

One of Lang's compelling ideas is that by recognizing and naming hitherto-unnamed evils, we simultaneously recognize the goods these evils assault. That is how moral imagination progresses. Thus, by recognizing the murder of groups as a distinctive form of evil and a distinctive crime, we simultaneously recognize the distinctive importance of groups and group rights (40-43).

Surely Lang is right that the concept of genocide implies the importance of groups as such. He is also right that the Convention Against Genocide (CAG) takes a step toward that recognition by distinguishing genocide - the murder of groups - from the mass murder of individuals (what international law labels the "crime against humanity of extermination"). As Lang reminds us, two of the Article 2 crimes in the CAG "do not involve the physical murder of individuals" and therefore "they make sense ... only when the purpose of designating genocide a crime is understood to construct protection for a group, not (primarily) for individuals" (91). ${ }^{1}$

But I am skeptical that talk of group rights aids us in understanding the importance of groups, and I doubt that the concept of group rights is "implicit" in the recognition of genocide as a crime, as Lang asserts (4). The specific group right that genocide attacks is "the group's right to exist in the future" (144). The right to exist, however, is a slippery concept, as becomes clear when we ask what the correlative duties to that right are, and on whom they fall. Notably, the CAG does not invoke group rights. The CAG enunciates just two pertinent duties, imposed on states: to prevent genocide and to punish it. ${ }^{2}$ Hence, the correlative "right to exist" is,

${ }^{1}$ Article 2(d) criminalizes "imposing measures intended to prevent births within a group," while 2(e) criminalizes "forcibly transferring children out of the group to another group." By contrast, the crime against humanity of extermination consists of killing one or more persons "as part of a mass killing of members of a civilian population." Elements 1 and 2 under Article 7(1)(b), ICC Elements of Crimes (2011), p. 6. Extermination, unlike genocide, requires killing and ignores birth-prevention and transfer of children.

${ }^{2}$ Even here, it remains radically unclear on whom the obligation to prevent and punish genocide falls. The International Court of Justice has declared that states' obligation to prevent genocide means the obligation "to employ all means reasonably available to them, so as to prevent genocide so far as possible" - but then the ICJ goes on to explain that what actions are "reasonably available" varies widely depending on a state's "capacity to influence" the genocidal actors, and may be limited by international law. Application of the Convention on the Prevention and Punishment of the Crime of Genocide (Bosn. \& Herz. v. Serb. \& Mont.), 2007 I.C.J. General List No. 91 (Judgment of Feb. 26), §430. I find the ICJ's opinion hopelessly, even disingenuously, wishy-washy - on the one hand 
simply, the right not to be targeted for destruction, that is, for genocide (132).

But this right does not entail a more robust right to exist, correlated with other duties. For example, one way religious groups cease to exist is that, over time, the ranks of the worshippers dwindle, through conversion or loss of faith. The pagan religions of Greece and Rome died by attrition, not by genocide, although Christian persecution of the pagans undoubtedly hastened their end. It makes little sense to say that these faith communities (as we might call them today) had a "right to exist," if this implies that at least some people had a duty to worship Zeus or Jupiter.

No group's right to exist implies a moral duty of continued membership on those born into it. Worse still would be a legally enforced duty not to exit; indeed, laws forbidding religious conversion violate both the Universal Declaration of Human Rights and the International Covenant on Civil and Political Rights. ${ }^{3}$ Although Lang acknowledges the tension between the supposed group right to exist and individuals' right to exit the group (141, $147)$, he brushes aside the problem it creates for a robust concept of group rights (147).

So too, a dwindling religious or linguistic community has no right to exist that implies a duty on the part of the larger community to keep it on artificial life support by pouring resources into it - for example, by subsidizing Gaelic schools in Ireland, or requiring Irish school children to study Gaelic. Well and good if Irish voters decide to take such steps to preserve the historical language; but the voters have no duty to do so - no more than the Norwegians have a duty to financially support the handful of Fricka-worshippers in their devotions. Here, again, Lang recognizes the problem (146-47), but he does not say whether he accepts or rejects a state duty to support groups against natural attrition, and he offers no defence of such a duty.

Once we distinguish the correlative duties, it seems clear that a group's right to exist is only its right to be protected from destruction (and persecution) - not its non-existent rights to block the voluntary exit of group members or to obtain state aid against natural attrition. The group's right to exist is thus a narrow right, not a broad right. It follows that to propose that the wrong of genocide

boldly announcing an erga omnes obligation to prevent genocide, but on the other hand giving states a trivially easy way out.

${ }^{3}$ Universal Declaration of Human Rights, art. 18; International Covenant on Civil and Political Rights, art. 18(2). 
is its violation of a group right to exist is a near-tautology. ${ }^{4}$ It wouldn't be if the group's right to exist entailed duties other than the right against genocide - but it does not. The vocabulary of group rights adds no explanatory power to accounts of why genocide is and must be a distinctive crime. And it runs the risk of obscuring the very real differences among correlative duties inherent in rights claims.

\section{Two Concepts of Group Value}

It is more helpful to talk about the value of groups as such, rather than group rights. The CAG protects groups because groups are valuable, not because they are rights-bearers. The value of groups can mean either or both of two things: their value to their members, or their value to others - to outsiders or to humanity as a whole. Lang focuses on the former. To explain the value of groups to their members, he argues quite plausibly that our selves are, fundamentally, social in nature. People "are part of a corporate or collective 'self' closely linked structurally and causally to their individual actions and achievements; their capacities and even inclinations within this collective would be foreign if not impossible for solitary individuals and even for individuals randomly joined" (29). National, religious, ethnic, and racial groups are especially salient in constructing our "social self" (194). That makes such groups "life-giving" (32) for the individual.

Additionally, Lang claims that the concept of genocide represents the group as a person, and "arguably, as ... an entity prior to the individual person" (32) - by which he evidently means ontologically prior, not only chronologically prior. The thesis of ontological priority of groups over their members is philosophically dubious, but undoubtedly group-identities matter to most people, which is really all Lang needs for his argument. ${ }^{5}$

The crucial question is whether groups have value to nonmembers as well as members. This question matters when we ask why the CAG imposes international obligations on states to combat genocide even if the victims are distant strangers in far-off lands. As Michael Ignatieff explains:

\footnotetext{
${ }^{4}$ Only a near-tautology, because I believe the group's right to exist also entails a duty to be protected from persecution and oppression short of genocide.

${ }^{5}$ I have criticized the strong ontological-priority thesis that groups "constitute" the individual self: David Luban, "The Self: Metaphysical Not Political," Legal Theory 1, no. 4 (1995): 401-437. But my argument does not deny that groups matter immensely to most of their members.
} 
When Claude Lanzmann was filming Shoah, he asked a Polish peasant whose fields abutted a death camp what he felt when he saw human ash from the crematoria chimneys raining down on his fields. The peasant replied: "When I cut my finger, I feel it. When you cut your finger, you feel it." The man's reply takes us to the heart of the problem of genocide. ... Why is a crime committed against Jews or any other human group a crime against those who do not belong to that group? ${ }^{6}$

The two most famous answers to Ignatieff's final question are those of Raphael Lemkin, one of Lang's heroes (125), and Hannah Arendt - and they are very different. ${ }^{7}$ Where Lemkin's explanation of the value of groups is universalist, Arendt's is radically pluralist.

For Lemkin, what makes groups valuable is the distinctive contributions that "nations" make to universal civilization. The Poles gave the world "a Copernicus, a Chopin, a Curie; the Czechs, a Huss, a Dvorak; the Greeks, a Plato and a Socrates; the Russians, a Tolstoy and a Shostakovich." 8 For Arendt, the evil of genocide is not that the nations are wellsprings feeding human civilization, but that genocide "is an attack upon human diversity as such, that is, upon a characteristic of the 'human status' without which the very words 'mankind' or 'humanity' would be devoid of meaning."9 Genocide matters internationally not because the victim group contributes to universal civilization but because without international legal protection, "no people on earth ... can feel reasonably assured of its continued existence" given the terrifying efficacy of modern military technology and the precedent the Holocaust sets. ${ }^{10}$

Lemkin's universalist theory of group value assumes a "world community," a cosmopolitan "heritage [that] is a product of the contributions of all people."11 Arendt's pluralist explanation assumes no such thing, and indeed the value she places on "human diversity as such" suggests the opposite, that what matters is

\footnotetext{
${ }^{6}$ Michael Ignatieff, "Lemkin's Word,” The New Republic, 26 February 2001, 25, available at https://newrepublic.com/article/62613/lemkins-word.

${ }^{7}$ Lang devotes a chapter of his book to each of them.

${ }^{8}$ Raphael Lemkin, Axis Rule in Occupied Europe: Laws of Occupation, Analysis of Government, Proposal for Redress (Washington, DC: Carnegie Endowment for International Peace, 1944), 91. See more generally 74-95.

${ }^{9}$ Hannah Arendt, Eichmann in Jerusalem: A Report on the Banality of Evil, rev. ed., (New York: Viking, 1963), 269.

${ }^{10}$ Arendt, Eichmann in Jerusalem, 273.

${ }^{11}$ Lemkin, Axis Rule in Occupied Europe, 91.
} 
difference rather than commonality. No doubt Lemkin's universalism and Arendt's pluralism aren't the only possible theories of group value, but they are the iconic ones. Disappointingly, Lang bypasses this crucial debate, and he offers no answer to Ignatieff's question: why is a crime committed against one group a crime against those outside that group? ${ }^{12}$

Perhaps Lang believes that the only value groups have is value to their members. If so, his theory is more individualistic than it seems, in the sense that he derives the value of groups entirely from their importance to the lives of their members. That is a respectable position. However, it implies that if membership in a national, ethnic, racial, or religious group ceases to be an important source of meaning for group members (perhaps because they have assimilated into their larger society), the group's value diminishes. This corollary would be a setback to the criminalization of genocide; presumably, Lang would not disagree.

Here, perhaps, a possible solution is one the ICTY proposed to answer the question of what constitutes an ethnic group, given that members' own level of ethnic self-identification varies. ICTY concluded that what matters is not self-identification but that their enemies stigmatize them as a group and target them accordingly. ${ }^{13}$ Analogously, perhaps what makes groups valuable enough to protect is, fundamentally, that the génocidaires think they are valuable enough to destroy.

\section{Pushback Against the Concept of Genocide}

Whether international law needs a separate crime of genocide in addition to the Nuremberg Charter's crime of extermination, and if so whether the CAG and the Rome Statute get the definition right, has been hotly disputed over the years. Lang devotes two chapters to rebutting critics of the concept of genocide: Marc Nichalanian, Larry May, and Paul Boghossian. I will not discuss Nichalanian or May, or Lang's responses to them, but I will make a few remarks about Lang's response to Boghossian's complaints about the legal definition of genocide.

Boghossian complains that key parts of the definition are arbitrary or vague. Why protect only national, ethnic, racial, and religious groups? Why not other categories, or different

\footnotetext{
${ }^{12}$ Lang does mention Lemkin's "civilization" theory in passing (131).

13 Prosecutor v. Jeliseć, Case No. IT-95-10-T, Judgment, §§70-71 (Dec. 14, 1999).
} 
categories? ${ }^{14}$ For instance, the Nuremberg Charter's definition of persecution contains a different list of protected groups: political, racial, or religious - and the Rome Statute of the ICC has yet another list of groups protected from persecution: political, racial, national, ethnic, cultural, religious, gender, or "other grounds that are universally recognised as impermissible under international law."15 When we lay the CAG side by side with these lists, the irresistible question is: why this one and not that one?

To this objection, Lang offers the right response: the four categories in the CAG are all groupings that recognizably matter to people, and nothing stops the UN or the ICC from eventually expanding the list of protected groups in the definition of genocide $(15,31-32,94)$. Lang could have made the case stronger, however, and warded off the counter-argument that reopening major international treaties is perilous, by referencing domestic law, which is far easier to change. Importantly, the genocide laws of several countries $d o$ expand the list. Colombia and Ethiopia include political groups, Lithuania includes political and social groups, and Costa Rica adds groups determined by age, political or sexual orientation, social position, economic situation, or civil status. France and Burkina Faso add to the CAG's list all groups determined by "any other arbitrary criterion." 16

Boghossian also objects to the CAG's definition of genocide as destruction of a protected group "in whole or in part," because of the fatal vagueness of "in part" - after all, even a single person is a part of her group. ${ }^{17}$ Again, Lang offers the right response: Boghossian reads the definition too formalistically; interpreted through its purpose and context, it is clear that the part must be substantial (93). Here too, Lang could have buttressed his case using legal sources. For example, the US genocide statute stipulates that the part must be substantial, and "substantial" means that destroying it would "cause the destruction of the group as a viable entity within the nation of which such group is a part."18 A viability test likewise underlies the ICTY's reasoning in its crucial Krstić decision, which found that the Srebreniča massacre was a genocide: killing the Muslim males and expelling the women from such a strategic

\footnotetext{
${ }^{14}$ Paul Boghossian, "The Concept of Genocide," Journal of Genocide Research 12, nos. 1-2 (2010): 74-75.

${ }^{15}$ Charter of the International Military Tribunal (Nuremberg Charter) (1946), art. 6(c); Rome Statute, art. 7(1)(h). These are my examples, not Boghossian's.

${ }^{16}$ All these statutes may be found in Prevent Genocide International, The Crime of Genocide in Domestic Laws and Penal Codes, available at http://preventgenocide.org/law/domestic/.

${ }^{17}$ Boghossian, "The Concept of Genocide," 75-76.

1818 U.S.C. $\$ 1093(8)$.
} 
location made a "viable" Muslim community around Srebrenica impossible. $^{19}$

I mention these legal points because they highlight one weakness of Lang's book: apart from the CAG, he ignores the law, even when it supports his conclusions. (So does Boghossian.) Jurists have devoted considerable thought to virtually every contestable clause of the genocide definition, and while the detailed treatments by the ICTY, ICTR, and ICC may well have gotten things wrong, philosophers should not ignore them and write their own analyses as if on a tabula rasa.

\section{The Tribalism Objection}

There is one important objection to the concept of genocide that Lang does not consider or rebut - and in my view it is the most consequential. The worry is that focusing on groups as such, rather than individuals, reinforces rather than combatting the kind of tribalism that gives rise to genocide. Philippe Sands reports that as early as 1945 the Austrian intellectual Leopold Kohr warned Lemkin that "by making groups the 'prime beneficiary' of protection and international law, Lemkin had fallen into a trap, adopting 'biological thinking' of the kind that led to anti-Semitism and anti-Germanism." 20 Perhaps this was why human rights groups opposed the CAG at the UN, to Lemkin's dismay. ${ }^{21}$ Sands largely agrees with Kohr's critique.

Apparently so did the great international lawyer Sir Hersh Lauterpacht, who was responsible for the term "crimes against humanity" in the Nuremberg Charter. Sands depicts Lauterpacht as Lemkin's intellectual adversary, precisely because Lauterpacht feared that emphasizing groups would devalue international human rights for individuals. ${ }^{22}$ Lauterpacht's opposition may explain why

\footnotetext{
${ }^{19}$ Prosecutor v. Krstić, Case No. IT-98-33-A, Appeals Judgment (Apr. 19, 2004), $\S 15$. Conversely, in its recent Mladić judgment, the ICTY Trial Chamber concluded that the Muslims killed in six other municipalities were not a "substantial part" of the Bosnian Muslims. Prosecutor v. Mladić, Case No. IT-0992-T, Trial Judgment, vol. 3 (Nov. 22, 2017), §§3527-3535 (pp. 1795-1801), available at http://www.icty.org/x/cases/mladic/tjug/en/171122-3of5_1.pdf.

${ }^{20}$ Philippe Sands, East-West Street: On the Origins of "Genocide" and "Crimes Against Humanity”, (New York: Knopf, 2016), 184-85. The internal quotations are from Kohr's letter to Lemkin.

${ }^{21}$ Raphael Lemkin, Totally Unofficial: The Autobiography of Raphael Lemkin, ed. Donna-Lee Frieze (New Haven, CT: Yale University Press, 2013), 170.

22 Sands, East-West Street, 110, 324, 327. Historian James Loeffler contends that Sands's contrast is overdrawn: far from being an individualist, Lauterpacht was a lifelong Zionist with a passionate concern for the rights of minority groups.
} 
Lemkin failed at Nuremberg. Although the Nuremberg indictment listed genocide among the war crimes, the lawyers and judges ignored it during the trial, instead convicting defendants of crimes against humanity. When the Tribunal read its verdict without mentioning genocide, Lemkin called it "the blackest day" of his life. ${ }^{23}$

Although Lang alludes to Lauterpacht's objection (175), he never confronts the worry that the concept of genocide might reinforce tribal thinking in the effort to prevent and punish its most lethal consequence.

\section{Intending Genocide Versus Intending Evil}

One of Lang's most significant claims is that anyone who commits genocide knows it is wrong $(38 ; 161)$. Here, he disagrees with Arendt, who thought she had discovered in Adolf Eichmann a "type of criminal, who ... commits his crimes under circumstances that make it well-nigh impossible for him to know or to feel that he is doing wrong." "24 What circumstances? She held that Germany had undergone a "moral collapse," in which rules like "Thou shalt not kill" were flipped upside-down. ${ }^{25}$ That made it hard for a moral chameleon like Eichmann, whose conscience mimicked the prevailing ideology, to recognize the evil he was doing. ${ }^{26}$ Lang, by contrast, asserts that nobody can fail to recognize the wrong in genocide, regardless of the prevailing ideology.

But this seems historically untrue. In the Hebrew Bible, God commands Saul to commit genocide, and then punishes him for disobeying - evidence, surely, that there was no condemnation of genocide in the ancient Middle East. ${ }^{27}$ Lang mentions this biblical passage $(53,162)$, but without drawing the conclusion that recognizing the evil of genocide depends on prevailing cultural norms. Perhaps he disagrees with Arendt because of skepticism that morality could invert itself so abruptly in Germany. It's true that

Rooted Cosmopolitans: Jews and Human Rights in the Twentieth Century (New Haven, CT: Yale University Press, forthcoming).

${ }^{23}$ Sands, East-West Street, 358.

${ }^{24}$ Arendt, Eichmann in Jerusalem, 276; also 26.

25 Arendt, Eichmann in Jerusalem, 125, 150. See also Arendt, "Personal Responsibility Under Dictatorship," in Responsibility and Judgment, ed. Jerome Kohn (New York: Schocken, 2003), 24, 34; "Some Questions of Moral Philosophy," in Responsibility and Judgment, 138.

${ }^{26}$ Several excellent historians, notably Bettina Stangneth, think Eichmann was in fact a dyed-in-the-wool antisemite. Lang argues that the source material Stangneth unearthed can bear either her interpretation or Arendt's (155-56). I agree.

271 Samuel 15:1-26. Saul did not shrink from genocide on moral grounds, for he killed all but one of the Amalekites. 
Arendt's "moral collapse" thesis raises perplexing questions of how morality unexpectedly turned upside-down. But Lang's view also invites a hard question: if the evil of genocide is self-evident, how did so many thousands of Germans and East Europeans deliberately choose it?

It seems that Lang's own understanding of how groups shape our consciousness and our choices should incline him more toward Arendt's explanation. Nazi ideology intensified us-versus-them group consciousness in the form of race hatred; and once it reached a tipping point, the abnormal became the new normal. Those who thoughtlessly identify doing the right thing with doing the normal thing - the group thing, one might say - will have a hard time recognizing evil when it is a group enterprise. Even the foot-soldiers who pull triggers may lack genocidal purpose, acting instead out of a shoulder-shrugging "ours not to reason why" outlook. Of course, they intend to kill, but that does not imply they intend to destroy the group as such, which in any case is beyond a foot-soldier's power. And their leaders have told them that if this is evil, it is a necessary evil - which may cause them to doubt it is evil at all.

The Lang-Arendt disagreement matters for the legal punishment of genocide. That is because the crime requires proof of genocidal intent. A consequence of Lang's view is that anyone who participates in genocide knows he is doing wrong: his knowledge of the genocide becomes morally equivalent with genocidal intent (3839, 105). Several prominent legal scholars likewise favor a knowledge-based theory of genocidal intent, precisely in order to ensure that foot-soldiers who knowingly engage in genocide cannot escape liability by denying they intended it. ${ }^{28}$ But this creates an anomaly: it makes foot-soldiers who merely went along just as culpable as the planners and organizers of genocide. That seems wrong-headed, and Lang himself is rightly repelled at "the prospect of hanging hundreds of thousands of active German agents" (162).

If there is any drafting flaw in the CAG, it lies in its awkward mash-up of individual intentions and inherently collective contexts, without distinguishing leaders from foot-soldiers. The CAG offers no legal definition of "a genocide," only of individual acts of genocide. ${ }^{29}$ Yet an individual killing cannot be an act of genocide unless it takes place as part of a genocide, that is, a group enterprise in which genocidal intention is unevenly distributed within the

${ }^{28}$ Sangkul Kim gives a helpful overview and critique of such knowledge-based theories of genocidal intent. A Collective Theory of Genocidal Intent (The Hague: T.M.C. Asser, 2016), 22-80.

${ }^{29} \mathrm{Kim}$, A Collective Theory of Genocidal Intent, 105. Kim's book is the most comprehensive treatment of genocidal intent, and he concludes that it is a mistake to focus on individual rather than collective intent. 
group. Lang, who has thought so deeply about group responsibility, ought to agree. 